\title{
无光敏剂参与的可见光诱导咪唑并[1,2-a]吡啶的三氟甲基化反应
}

\author{
姚瑞超 $a$ 陈文博 $*, a$ 沈其龙 $*, b, c$ \\ ( ${ }^{a}$ 上海电力大学 上海市电力材料防护与新材料重点实验室 上海 200090) \\ ( $b$ 中国科学院上海有机化学研究所 分子合成卓越中心 中国科学院有机氟化学重点实验室 上海 200032) \\ $\left({ }^{c}\right.$ 中国科学院大学 北京 100049)
}

\begin{abstract}
摘要 发展了一个无光敏剂参与的可见光促进的咪唑并 $[1,2-a]$ 吡啶衍生物的三氟甲基化新反应. 该反应利用本课题组 此前发展的基于硫叶立德骨架的亲电三氟甲基化试剂作为三氟甲基自由基源，反应条件温和，底物普适性好，同时兼 容常见的官能团. 机理研究表明该反应可被自由基捕获剂阻断. 对两个反应底物及它们的 $1: 1$ 混合物的紫外-可见光 吸收光谱进行了研究, 研究表明三氟甲基化试剂与咪夾并 [1,2- $a$ 吡啶之间形成了一个 Donor-Acceptor 加合物. 在此基 础上提出了一个合理的机理, 即该加合物在光照条件下被激发, 发生硫-三氟甲基键均裂生成三氟甲基自由基, 该自由 基与咪㛗并 $[1,2-a]$ 吡啶发生自由基取代反应. 同时也成功地将该方法应用于治疗胃溃疡药物佐利米定的三氟甲基化衍 生物的合成.
\end{abstract}

关键词 三氟甲基; 可见光; 无光敏剂; 咪唑并 $[1,2-a]$ 吡啶

\section{Photosensitizer-Free Visible-Light-Promoted Trifluoromethylation of Imidazo[1,2-a]pyridines}

\author{
Yao, Ruichao $^{a} \quad$ Chen, Wenbo ${ }^{*, a} \quad$ Shen, Qilong*,b,c \\ ( ${ }^{a}$ Shanghai Key Laboratory of Materials Protection and Advanced Materials in Electric Power, Shanghai University of \\ Electric Power, Shanghai 200090) \\ $\left({ }^{b}\right.$ CAS Key Laboratory of Organofluorine Chemistry, Center for Excellence in Molecular Synthesis, Shanghai Institute of Or- \\ ganic Chemistry, Chinese Academy of Sciences, Shanghai 200032) \\ ( ${ }^{c}$ University of Chinese Academy of Sciences, Beijing 100049)
}

\begin{abstract}
A photosensitizer-free visible-light-promoted method for direct trifluoromethylation of imidazo[1,2- $a]$ pyridine derivatives using an electrophilic trifluoromethylating reagent based on sulfonium ylide skeleton was described. The reaction occurred in broad substrate scope under mild conditions and tolerant various functional groups. Initial mechanistic experiments including reactions in the presence of radical scavengers and UV absorption spectroscopic studies were conducted. Inhibition by the radical scavengers were observed. In addition, an extra-absorption peak between $500 \sim 510 \mathrm{~nm}$ in UV-Vis absorption spectrum was observed. These observations led us to propose a working mechanism. Finally, application of the current method for the preparation of trifluoromethylated derivative of gastroproctive drug zolimidine was demonstrated.

Keywords trifluoromethyl; visible light; photosensitizer free; imidazo[1,2-a]pyridine
\end{abstract}

\section{Introduction}

Mainly due to its broad applications in medicinal chemistry, imidazo[1,2-a]pyridine, a unique fused bicyclic $5 / 6$ heterocycle, is generally considered by the medicinal chemists as one of the core structural motifs in new drug design. ${ }^{[1]}$ In fact, a number of drug molecules with imidazo[1,2-a]pyridine unit including anxiolytic drug alpidem, ${ }^{[2]}$ nonbenzodiazepine $\mathrm{Z}$ drug zolpidem ${ }^{[3]}$ which is used for the treatment of insomnia, gastroproctive drug

\footnotetext{
* Corresponding authors. E-mail: shenq1@mail.sioc.ac.cn; wenbochen@shiep.edu.cn Received March 2, 2021; revised March 25, 2021; published online April 9, 2021.

Project supported by the National Natural Science Foundation of China (No. 21625206), the Strategic Priority Research Program of the Chinese Academy of Sciences (No. XDB20000000), the Natural Science Foundation of Shanghai (No. 20ZR1471600) and the Science and Technology Commission of Shanghai Municipality (No. 19DZ2271100).

国家自然科学基金(No. 21625206)、中国科学院战略性先导科技专项(B 类) (No. XDB20000000)、上海市自然科学基金(No. 20ZR1471600)和上海市科 学技术委员会(No. 19DZ2271100)资助项目.
} 
zolimidine $^{[4]}$ sedative drug saripidem ${ }^{[5]}$ have been approved and marketed previously (Figure 1). On the other hand, in recent years, "Fluorine scan", which refers to install a fluorine atom or a fluoroalkyl group onto the drug candidates, became a popular strategy to further improve the molecule's pharmacokinetics including its membrane permeability and metabolic stability. ${ }^{[6]}$ It is, therefore, speculated whether the incorporation of a fluoroalkyl group onto imidazo[1,2-a]pyridine core unit might benefit its biological activities and potentially facilitate the new drug process.

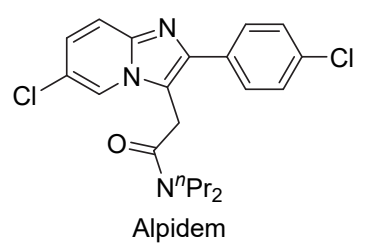<smiles>Cc1ccc(-c2nc3ccc(C)cn3c2CC(=O)OCc2ccccc2)cc1</smiles>

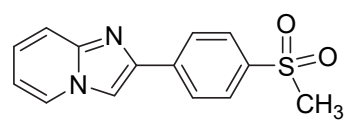

Zolimidine

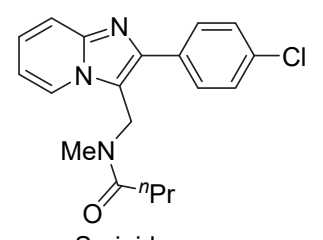

Saripidem
Figure 1 Drug molecules with an imidazo[1,2- $a$ ]pyridine core

Toward this end, a number of methods have been recently reported for the preparation of the trifluoromethylsubstituted imidazo[1,2-a]pyridine derivatives (Scheme 1). In general, these methods can be divided into three different categories. (1) Transition-metal catalyzed radical trifluoromethylation of imidazo[1,2-a]pyridine. For instance, Hajra and coworkers described the first Ag-catalyzed oxidative trifluoromethylation of imidazo[1,2-a]pyridine derivatives using cheap and easily available $\mathrm{CF}_{3} \mathrm{SO}_{2} \mathrm{Na}$ as the trifluoromethyl radical source and tert-butyl hydroperoxide (TBHP) as the oxidant. ${ }^{[7]}$ Subsequently, Wang, Leng and $\mathrm{Wu}$, and Tang independently reported alternative methods utilizing nickel or copper catalyst and $\mathrm{CF}_{3} \mathrm{I}$ or 1-trifluoromethyl-1,2-benziodoxol-3(1H)-one (Togni's reagent) as the trifluoromethyl radical source.$^{[8-10]}(2)$ Transition metal-free direct trifluoromethylation of imidazo[1,2-a]pyridine derivatives. In this respect, $\mathrm{Zou}, \mathrm{Wu}, \mathrm{Wu}$ and their coworkers reported that the reaction of Togni's reagent with imidazo[1,2- a]pyridine derivatives in $\mathrm{CH}_{3} \mathrm{CN}$ in the presence of $\mathrm{K}_{2} \mathrm{CO}_{3}$ occurred smoothly at $75{ }^{\circ} \mathrm{C}$ after $6 \mathrm{~h}$ to give the corresponding trifluoromethylated imidazo$[1,2-a]$ pyridines in good yields. ${ }^{[11]}$ Furthermore, the same group found that in this reaction, Togni's reagent could be replaced by a combination $\mathrm{PhI}(\mathrm{OAc})_{2} / \mathrm{TMSCF}_{3}$, thus circumventing the use of potential explosive reagent. ${ }^{[12]}$ (3) Visible-light-promoted radical trifluoromethylation of imidazo[1,2-a]pyridines in the presence of different photosensitizers. For example, Rueping, Zhang and Cui separately reported this type of transformation using different photosensitizers including 4,4'-dimethoxybenzophenone, ${ }^{[13]}$ anthraquinone-2-carboxylic acid $\left(\mathrm{AQN}-2-\mathrm{CO}_{2} \mathrm{H}\right)^{[14]}$ and 9-mesityl-3,6-di-tert-butyl-10-phenylacridinium tetrafluoroborate, ${ }^{[15]}$ respectively. Nevertheless, these methods typically required the use of either a transition metal catalyst, an oxidant or a photosensitizer. Thus, new methods that could efficiently introduce the trifluoromethyl group onto imidazo[1,2- $a$ ] pyridine and avoid the use of transition metal catalyst/oxidant/photosensitizer are needed.

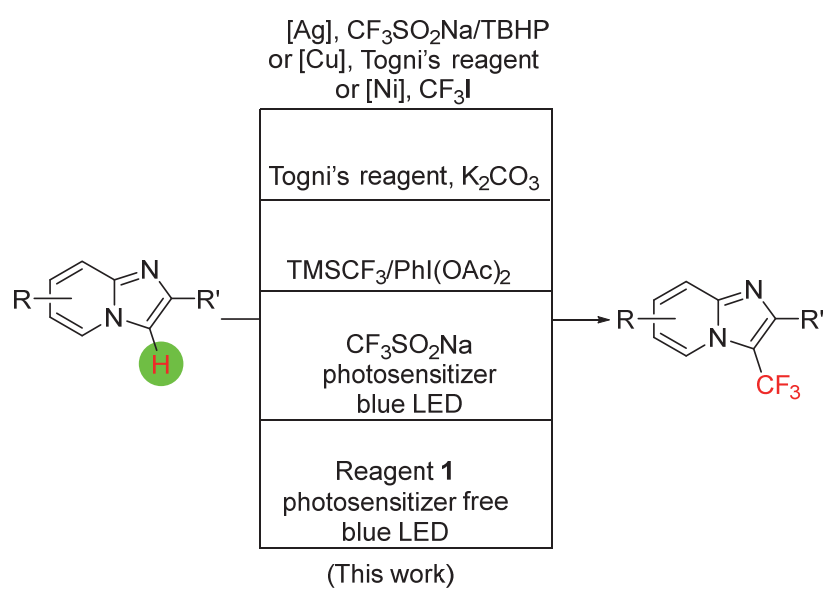

Scheme 1 Approaches for the preparation of trifluoromethylated imidazo[1,2-a]pyridine derivatives

Very recently, our group developed a shelf-stable yet highly reactive electrophilic trifluoromethylating reagent (trifluoromethyl)(4-nitrophenyl)bis(carbomethoxy)methylide (1) ${ }^{[16]}$ with a sulfonium ylide skeleton ${ }^{[17]}$. The reagent was prepared from cheap and easily available starting material 4-nitrophenyl disulfide, $\mathrm{TMSCF}_{3}$ and dimethyl diazomalonate in two steps in high yields. More importantly, the procedure could be readily scaled up, thus rendering reagent 1 a promising electrophilic trifluoromethylating reagent with great potential applications. During the exploration the reactivity of this reagent, we discovered that using 1,8-diazzbicycle[5.4.0]undec-7-ene (DBU) as the base, trifluoromethyl radical could be efficiently generated upon irradiation of a solution of reagent $\mathbf{1}$ in dimethyl sulfoxide (DMSO) with blue light emitting diode (LED) at room temperature in the absence of any photosensitizer. Consequently, a method for direct trifluoromethylation of a variety of electron-rich arenes and heteroarenes such as indoles and pyrroles was then established. ${ }^{[16]}$ Considering the importance of the imidazo[1,2-a]pyridine in the field of pharmaceutical industry and the potential of the trifluoromethylated imidazo[1,2-a]pyridine for new drug discovered, we asked ourselves whether the protocol could be applied to trifluoromethylated imidazo[1,2-a]pyridines using reagent 1 as the trifluoromethyl radical source. Our investigation demonstrated that the method worked as expected. Moreover, out of our expectation, control experiments that the use of a base was not required, thus making this approach very attractive for the preparation of such a trifluoromethylated imidazo[1,2- $a$ ] pyridine derivatives. Herein, we would like to report these discoveries. 


\section{Results and discussion}

\subsection{Optimization of the reaction conditions}

Reaction of 2-phenyl imidazo[1,2-a]pyridine with reagent 1 in DMSO in the presence of 1.5 equiv. of DBU under the irradiation of blue LED was initially examined. ${ }^{[18]}$ The reaction worked smoothly after $24 \mathrm{~h}$ at room temperature to give the desired product 2-phenyl-3-(trifluoromethyl)imidazo[1,2-a]pyridine (2a) in 68\% yield, as expected (Table 1, Entry 1). However, to our surprise, the same reaction in the absence of DBU also occurred in full conversion under otherwise identical conditions to give compound $\mathbf{2 a}$ in $82 \%$ yield (Table 1, Entry 2). To probe whether the solvent played an important role in promoting the reaction, we next studied the reaction in a variety of solvents with different polarity. It was found that reaction in polar, aprotic solvents such as $\mathrm{N}, \mathrm{N}$-dimethylformamide (DMF), $N, N$-dimethylacetamide (DMAc), $\mathrm{CH}_{3} \mathrm{CN}$ or $\mathrm{CH}_{3} \mathrm{OH}$ occurred in full conversion after $24 \mathrm{~h}$ irradiation. Nevertheless, the yields of these reaction decreased to $44 \% \sim 75 \%$ (Table 1, Entries 3 6). Likewise, reaction in less polar solvent $\mathrm{CH}_{2} \mathrm{Cl}_{2}$ which has been frequently employed as the solvent in radical reactions occurred in 59\% yield (Table 1, Entry 7). However, reactions in solvents such as tetrahydrofuran (THF) and toluene that bears a weak $\mathrm{C}-\mathrm{H}$ bond occurred in low yields $(13 \% \sim 17 \%)$ (Table 1, Entries 8 9). Next, we investigated that if the reaction required $24 \mathrm{~h}$ to occur to full conversion. Parallel experiments that terminated after 4,12 and $18 \mathrm{~h}$ gave the

Table 1 Optimization of the conditions for visible-lightpromoted trifluoromethylation of 2-phenyl imidazo[1,2-a]pyridine with reagent 1

\begin{tabular}{clcc}
\hline Entry & Solvent & Time/h & Yield/\% \\
\hline 1 & DMSO & 24 & $68^{b}$ \\
2 & $\mathrm{DMSO}$ & 24 & $82\left(70^{c}\right)$ \\
3 & $\mathrm{DMF}$ & 24 & 61 \\
4 & $\mathrm{DMAc}$ & 24 & 75 \\
5 & $\mathrm{CH} \mathrm{CN}_{2}$ & 24 & 44 \\
6 & $\mathrm{CH}_{3} \mathrm{OH}$ & 24 & 61 \\
7 & $\mathrm{CH}_{2} \mathrm{Cl}{ }_{2}$ & 24 & 59 \\
8 & $\mathrm{THF}$ & 24 & 17 \\
9 & $\mathrm{Toluene}$ & 24 & 13 \\
10 & $\mathrm{DMSO}$ & 18 & 79 \\
11 & $\mathrm{DMSO}$ & 12 & 64 \\
12 & $\mathrm{DMSO}$ & 4 & 26 \\
$13^{d}$ & $\mathrm{DMSO}$ & 24 & 72 \\
$14^{e}$ & $\mathrm{DMSO}$ & 24 & - \\
\hline
\end{tabular}

${ }^{a}$ Reaction conditions: 2-phenyl imidazo[1,2-a]pyridine (0.1 mmol), reagent 1 $(0.15 \mathrm{mmol})$ in solvent $(1.0 \mathrm{~mL})$ under blue LED at room temperature for $24 \mathrm{~h}$; ${ }^{b}$ DBU (1.5 equiv.) were used; ${ }^{c}$ Isolated yield; ${ }^{d}$ Reagent 1 (1.2 mmol) was used; ${ }^{e}$ Reaction under dark. trifluoromethylated product in $26 \%, 64 \%$ and $79 \%$ yields, respectively (Table 1, Entries 10 12), suggesting the necessity of long reaction time to ensure full conversion. Finally, we conducted a control experiment to determine whether the blue LED light was required. It was found that in the absence of the blue LED, the formation of the desired trifluoromethylated product $\mathbf{2 a}$ was not observed.

\subsection{Scope of the reaction}

Under the optimal conditions as shown in Entry 2 in Table 1 for the formation trifluoromethylated imidazo[1,2$a$ ]pyridine derivatives, we next explored the generality of imidazo[1,2-a]pyridine derivatives and the results were summarized in Table 2. In general, 2-aryl substituted imidazo[1,2-a]pyridines with both electron-donating or electron-withdrawing groups at the aryl moiety reacted with reagent 1 to give the corresponding trifluoromethylated imidazo[1,2- $a$ ]pyridine derivatives in good yields (Table 2, $\mathbf{2 a} \sim \mathbf{2 q})$. For example, the reactions of 2-(4-methoxyphenyl)-imidazo[1,2- $a$ ]pyridine or 2-(4-cyanophenyl)imidazo[1,2-a]pyridine with reagent $\mathbf{1}$ afforded the corresponding trifluoromethylated products $\mathbf{2 d}$ and $\mathbf{2 n}$ in $72 \%$ and $50 \%$ yields, respectively (Table 2, 2d and 2 n). Likewise, imidazo[1,2-a]pyridine derivatives with a substituent on the bicyclic heteroarene moiety also reacted efficiently to generate the trifluoromethylated products in good yields (Table 2, 2rr $\sim \mathbf{2 y}$ ). For instance, 8- or 7-methyl-substituted imidazo[1,2-a]pyridine derivatives reacted to give 3 -trifluoromethylated imidazo[1,2-a]pyridines $\mathbf{2 r}$ and $\mathbf{2 s}$ in $53 \%$ and $73 \%$ yields, respectively (Table 2, 2r $\sim 2 \mathbf{s}$ ). In addition, 3-trifluomethylated products were formed whatever the substituent on the bicyclic heteroarene moiety is electron-donating or electron-withdrawing group. Reactions of both 3-phenyl-6-methoxyimidazo[1,2-a]pyridine and 3-phenyl-7-methoxycarbonylimidazo[1,2-a]pyridine with reagent 1 to give the corresponding 3-trifluoromethylated heteroarenes in $70 \%$ and $50 \%$ yields, respectively (Table $2, \mathbf{2 v} \sim \mathbf{2 w}$ ). Furthermore, we found that 2-alkyl-substituted imidazo[1,2- $a$ ]pyridine also reacted at 3 -position to give compound $\mathbf{2 x}$ in $40 \%$ yield (Table 2, $\mathbf{2 x}$ ). Finally, an analogous bicyclic heteroarene compound 6-phenylimidazo[2,1-b]thiazole reacted with reagent 1 under the optimized conditions to give compound $\mathbf{2 y}$ in $65 \%$ yield (Table 2, 2y). Notably, imidazo[1,2-a]pyridine derivatives with a halogen including chloride, bromide or iodide at different positions also reacted to give the corresponding 3-trifluoromethylated products $(\mathbf{2} \mathbf{k} \sim \mathbf{2 m}, \mathbf{2 q}$ and $\mathbf{2 t} \sim \mathbf{2 u}$ ), rendering them to be easily further functional group transformation under classic transition-metal catalyzed cross-coupling. Similarly, the ester groups in compounds 20 and $\mathbf{2 w}$ were amenable to be converted to other carbonyl derivatives easily, thus providing additional points for functionalization (Table 2, $\mathbf{2 n}$ and $\mathbf{2 v}$ ).

\subsection{Mechanistic investigation}

Presumptively, the blue LED-promoted trifluoromethylation of imidazo[1,2- $a$ ]pyridine is proposed to proceed via a radical substitution reaction. To gain some understanding 
Table 2 Scope for visible-light-promoted trifluoromethylation of 2-phenyl imidazo[1,2-a]pyridine with reagent 1<smiles>[R]c1ccn2c(C)c([R])nc2c1C(=O)OC</smiles>

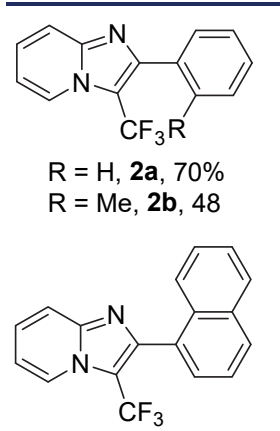

2g, $47 \%$<smiles>FC(F)(F)c1c(-c2ccc(Br)cc2)nc2ccccn12</smiles>

2I, $69 \%$<smiles>FC(F)(F)c1c(-c2cccc(Br)c2)nc2ccccn12</smiles>

2q, $65 \%$<smiles>Cc1ccc(-c2nc3ccccn3c2C(F)(F)F)cc1</smiles>

2c, $77 \%$<smiles>FC(F)(F)c1c(-c2ccc3c(c2)Cc2ccccc2-3)nc2ccccn12</smiles>

2h, $64 \%$<smiles>Cc1ccc(-c2nc3ccccn3c2C(F)(F)F)cc1</smiles>

$2 \mathrm{~m}, 71 \%$<smiles>Cc1cccn2c(C(F)(F)F)c(-c3ccccc3)nc12</smiles>

2r, $53 \%$<smiles>COc1ccc(-c2nc3ccccn3c2C(F)(F)F)cc1</smiles>

2d, $72 \%$<smiles>FC(F)(F)c1c(-c2cccs2)nc2ccccn12</smiles>

2i, $49 \%$<smiles>N#Cc1ccc(-c2nc3ccccn3c2C(F)(F)F)cc1</smiles>

2n, $50 \%$<smiles>COc1ccc(-c2nc3ccccn3c2C(F)(F)F)cc1</smiles>

2e, $68 \%$<smiles>Fc1ccc(-c2nc3ccccn3c2C(F)(F)F)cc1</smiles>

2j, $72 \%$<smiles>CC(=O)c1ccc(-c2nc3ccccn3c2C(F)(F)F)cc1</smiles>

2o, $46 \%$

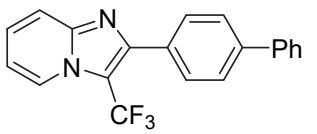

2f, $47 \%$<smiles>COc1ccc2nc(-c3ccccc3)c(C(F)(F)F)n2c1</smiles>

2v, $70 \%$<smiles>Cc1ccn2c(C(F)(F)F)c(-c3ccccc3)nc2c1</smiles>

2s, $73 \%$<smiles>FC(F)(F)c1c(-c2ccccc2)nc2cc(Cl)ccn12</smiles>

2t, $46 \%$<smiles>FC(F)(F)c1c(-c2ccc(Cl)cc2)nc2ccccn12</smiles>

2k, $67 \%$

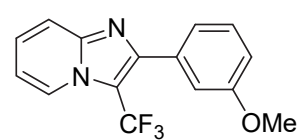

2p, $62 \%$<smiles>CC(=O)c1ccn2c(C(F)(F)F)c(-c3ccccc3)nc2c1</smiles>

2w, $50 \%$<smiles>Cc1nc2ccc(Cl)cn2c1C(F)(F)F</smiles>

2x, $40 \%$

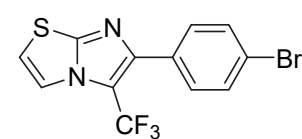

$2 y, 65 \%$

${ }^{a}$ Reaction conditions: 2-phenyl imidazo[1,2-a]pyridine $(0.1 \mathrm{mmol})$, reagent $1(0.15 \mathrm{mmol})$ in DMSO $(1.0 \mathrm{~mL})$ under blue LED at room temperature for $24 \mathrm{~h}$.

about the mechanism of the reaction, we conducted a few experiments to probe whether a free radical is involved in the reaction. First, we conducted four parallel experiments in the presence of 2.0 equiv. of different radical scavengers. As shown in Scheme 2, reaction using 2,2,6,6-tetramethylpiperidinooxy (TEMPO) as the radical inhibitor was completely shut down and the reaction in the air gave much lower yield, while the reaction with 2,6-di-tert-butyl4-methylphenol (BHT) was not affected at all. From these

$$
\begin{gathered}
\text { Nene: } 82 \% \\
\text { TEMPO (2.0 equiv.): } 0 \% \\
\text { Under air: } 24 \% \\
\text { BHT (2.0 equiv.): } 85 \%
\end{gathered}
$$

Scheme 2 Visible-light-promoted trifluoromethylation of 2phenyl imidazo[1,2- $a$ ]pyridine with reagent $\mathbf{1}$ in the presence of radical inhibitors observations, we can assume that free radical is involved in the reaction, and the fact that the yield of the reaction was not affected by the addition of BHT could be explained by the lower competitive ability of electron-rich arene BHT than that of imidazo[1,2-a]pyridine.

To gain more insight about the reaction, a competition experiment of $1: 1$ mixture of the imidazo[1,2- $a$ ]pyridines with an electron-rich methoxy group and an electron-withdrawing ester group with 0.33 equiv. of reagent 1 was conducted (Eq. 1). It was found that the ratio for the formation of compounds $\mathbf{2 d}$ and $\mathbf{2 0}$ was $2: 1$, as determined by the ${ }^{19} \mathrm{~F}$ NMR spectroscopy of the reaction mixture. Since the trifluoromethyl radical is electrophilic, the higher ratio for electron-rich substrate is consistent with the radical nature of the reaction.

To probe the reason why photosensitizer is not required for the reaction, we studied the UV-Vis absorption of the DMSO solution of both imidazo[1,2- $a$ ]pyridine substrate and reagent 1 , as well as the $1: 1$ adduct of two reagents (Figure 2). The UV-Vis absorption spectra of both imidazo[1,2-a]pyridine substrate and reagent 1 showed weak absorption below $500 \mathrm{~nm}$. Instead, a new absorption peak 


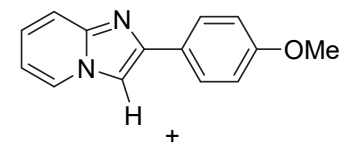<smiles>COC(=O)C(C(=O)OC)=S(c1ccc([N+](=O)[O-])cc1)C(F)(F)F</smiles>

$(1.5: 1.5: 1)$

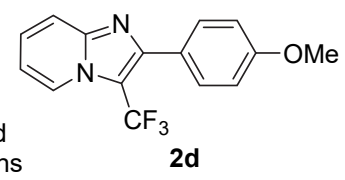

(1)

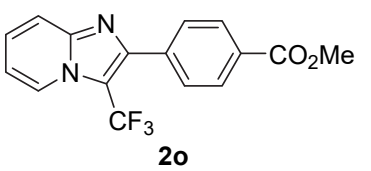

$32 \%$ conversion of reagent 1

$2 d: 20=2: 1$ between $500 \sim 510 \mathrm{~nm}$ was observed for the $1: 1$ adduct of two reagents, indicating that a donor-acceptor complex is generated, which might act as the photosensitizer for the reaction. ${ }^{[19]}$ Furthermore, the color of the $1: 1$ mixture of imidazo[1,2- $a$ ]pyridine substrate and reagent $\mathbf{1}$ in DMSO turned yellow, thus providing evidence that the donor-acceptor complex is indeed formed (See Supporting Information for details).

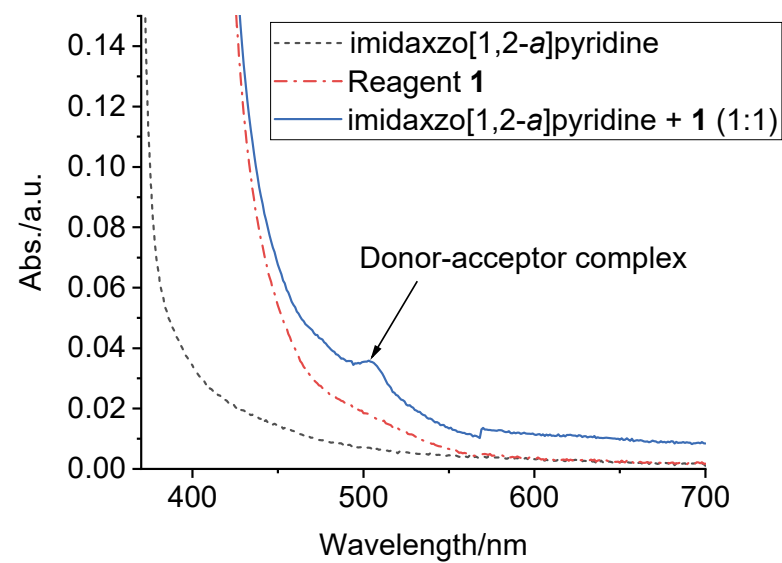

Figure 2 UV-Vis absorption spectra of 2-phenyl imidazo[1,2a]pyridine, reagent 1 and $1: 1$ adduct of two compounds in DMSO

Based on these initial experiments, we propose a working mechanism for the current visible-light-promoted photosensitizer-free trifluoromethylation of imidazo[1,2- $a$ ]pyridines, as shown in Scheme 3. At beginning, a donoracceptor between imidazo[1,2- $a$ ]pyridine substrate and reagent $\mathbf{1}$ is formed. Upon irradiation with blue LED, the adduct is excited and the $\mathrm{S}-\mathrm{CF}_{3}$ in reagent $\mathbf{1}$ is homolytically cleaved to give a trifluoromethyl radical and a carbon radical A. Attack of the trifluoromethyl radical to the imidazo[1,2- $a$ ]pyridine substrate which preferentially takes place at the most electron-rich position to give a stabilized radical intermediate $\mathbf{B}$. Abstraction of the hydrogen in intermediate $\mathbf{B}$ by the carbon radical $\mathbf{A}$ generates the final product.

Finally, to demonstrate the utility of the current trifluoromethylation protocol, we attempted to prepare the tri-<smiles>COC(=O)C(C(=O)OC)S(C)(c1ccc([N+](=O)[O-])cc1)C(F)(F)F</smiles><smiles>COC(=O)C(C(=O)OC)S(CC(F)(F)F)(C(=O)OC)c1ccc([N+](=O)[O-])cc1</smiles><smiles>FC(F)(F)c1c(-c2ccccc2)nc2ccccn12</smiles><smiles>COC(=O)C(C(=O)OC)C(=O)OC</smiles>

Scheme 3 Proposed mechanism for visible-light-promoted trifluoromethylation of 2-phenyl imidazo[1,2-a]pyridine with reagent 1

fluoromethylated derivative of gastroproctive drug zolimidine. As shown in Eq. 2, the reaction of zolimidine with reagent 1 under the standard conditions afforded the desired trifluoromethylated zolimidine in $43 \%$ yield, thus providing evidence that the current method is a straightforward method for direct trifluoromethylative derivatization of drug molecules.

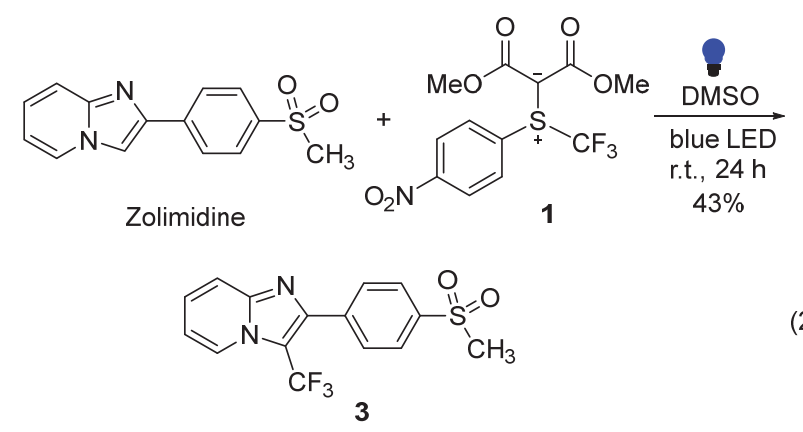

\section{Conclusions}

We successfully developed a photosensitizer-free visible-light-promoted method for the direct trifluoromethylation of imidazo[1,2- $a$ ]pyridine derivatives. The reaction occurred mild conditions and a variety of common functional groups were compatible. Initial mechanistic studied showed that the reaction was inhibited by the radical scavengers. UV-Vis absorption spectroscopic studies suggest that a $1: 1$ donor-acceptor adduct is formed which acts as the photosensitizer to activate reagent $\mathbf{1}$ to generate trifluoromethyl radical. Based on these observations, a reasonable working mechanism was proposed. Furthermore, a 
demonstration of the protocol for the preparation of trifluoromethylated derivative of gastroproctive drug zolimidine was provided. Currently, extending the current photosensitizer-free visible-light-promoted trifluoromethylation using reagent $\mathbf{1}$ as the trifluoromethyl radical source protocol to other electron-rich heteroarenes is undergoing in our laboratory.

\section{Experimental section}

\subsection{General information}

${ }^{1} \mathrm{H}$ NMR and ${ }^{13} \mathrm{C}$ NMR spectra were recorded on 400 $\mathrm{MHz}$ and $500 \mathrm{MHz}$ spectrometer and are calibrated using residual undeuterated solvent $\left(\mathrm{CHCl}_{3}\right.$ at $\delta 7.26$ for ${ }^{1} \mathrm{H}$ NMR, $\delta 77.16$ for ${ }^{13} \mathrm{C}$ NMR). ${ }^{19} \mathrm{~F}$ NMR was recorded on $400 \mathrm{MHz}$ spectrometer $\left(\mathrm{CFCl}_{3}\right.$ as an external standard and low field is positive). NMR yield was determined by ${ }^{19} \mathrm{~F}$ NMR using benzotrifluoride as an internal standard before working up the reaction. Flash column chromatograph was carried out using 300 400 mesh silica gel at medium pressure.

\subsection{Materials}

All reagents were received from commercial sources. Solvents were freshly dried and degassed according to the purification handbook Purification of Laboratory Chemicals before using. Imidazo[1,2-a]pyridines were prepared according to a procedure reported in the literature. ${ }^{[20]}$ Reagent 1 was prepared according to a procedure reported in the literature. ${ }^{[16]}$

4.3 General procedure for visible-light-promoted trifluoromethylation of imidazo[1,2-a]pyridines with reagent 1

To a Schlenk tube equipped with a stir bar was added imidazo[1,2- $a$ ]pyridine $(0.3 \mathrm{mmol})$, reagent $1(0.45 \mathrm{mmol})$. The system was evacuated and refilled three times with argon. DMSO $(3.0 \mathrm{~mL})$ was added and the mixture was stirred under $3 \mathrm{~W}$ blue LED light for $24 \mathrm{~h}$. After the reaction was finished, water was added and the mixture was extracted with ethyl acetate $(20 \mathrm{~mL} \times 3)$. The organic layers were combined, dried over anhydrous $\mathrm{Na}_{2} \mathrm{SO}_{4}$, filtered and concentrated. The residue was purified by silica gel chromatography eluted with petroleum ether/ethyl acetate to give the corresponding product.

2-Phenyl-3-(trifluoromethyl)imidazo[1,2-a]pyridine (2a): ${ }^{[15]}$ White solid $(55 \mathrm{mg}, 70 \%)$, m.p. $70 \sim 72{ }^{\circ} \mathrm{C}$ (lit. ${ }^{[12]}$ m.p. $\left.71 \sim 72{ }^{\circ} \mathrm{C}\right)$. Eluent: ethyl acetate/petroleum ether $(V: V=1: 3), R_{\mathrm{f}}=0.3 .{ }^{1} \mathrm{H} \mathrm{NMR}\left(400 \mathrm{MHz}, \mathrm{CDCl}_{3}\right) \delta$ : 8.32 (d, $J=6.9 \mathrm{~Hz}, 1 \mathrm{H}), 7.74$ (d, $J=9.1 \mathrm{~Hz}, 1 \mathrm{H}), 7.70$ (d, $J=6.8 \mathrm{~Hz}, 2 \mathrm{H}), 7.50 \sim 7.43(\mathrm{~m}, 3 \mathrm{H}), 7.40(\mathrm{t}, J=8.0 \mathrm{~Hz}$, $1 \mathrm{H}), 7.00$ (t, $J=8.0 \mathrm{~Hz}, 1 \mathrm{H}) ;{ }^{19} \mathrm{~F} \mathrm{NMR}\left(376 \mathrm{MHz}, \mathrm{CDCl}_{3}\right)$ $\delta$ : $-57.71 ;{ }^{13} \mathrm{C}$ NMR $\left(126 \mathrm{MHz}, \mathrm{CDCl}_{3}\right) \delta: 148.2,146.2$, $133.0,129.7,129.1,128.3,127.1,125.7$ (q, $J=6.3 \mathrm{~Hz}$ ), $122.0(\mathrm{q}, J=267.1 \mathrm{~Hz}), 118.2,114.1,109.7$ (q, $J=40.3$ $\mathrm{Hz})$.

2-(o-Tolyl)-3-(trifluoromethyl)imidazo[1,2-a]pyridine (2b): ${ }^{[15]}$ Yellow oil (40 mg, 48\%). Eluent: acetone/petro- leum ether $(V: V=1: 7), R_{\mathrm{f}}=0.3 .{ }^{1} \mathrm{H}$ NMR $(400 \mathrm{MHz}$, $\left.\mathrm{CDCl}_{3}\right) \delta: 8.30(\mathrm{~d}, J=6.7 \mathrm{~Hz}, 1 \mathrm{H}), 7.72(\mathrm{~d}, J=9.0 \mathrm{~Hz}$, $1 \mathrm{H}), 7.39(\mathrm{t}, J=8.0 \mathrm{~Hz}, 1 \mathrm{H}), 7.33 \sim 7.22(\mathrm{~m}, 4 \mathrm{H}), 7.01(\mathrm{t}$, $J=8.0 \mathrm{~Hz}, 1 \mathrm{H}), 2.26(\mathrm{~s}, 3 \mathrm{H}) ;{ }^{19} \mathrm{~F} \mathrm{NMR}\left(376 \mathrm{MHz} \mathrm{CDCl}_{3}\right)$ $\delta:-59.43 ;{ }^{13} \mathrm{C}$ NMR $\left(126 \mathrm{MHz}, \mathrm{CDCl}_{3}\right) \delta: 147.7,146.1$, $137.1,132.7,130.3,130.1,129.0,127.0,125.4,121.8(\mathrm{q}$, $J=268.4 \mathrm{~Hz}), 118.6,114.0,110.8$ (q, $J=40.3 \mathrm{~Hz}), 19.9$.

2-(p-Tolyl)-3-(trifluoromethyl)imidazo[1,2-a]pyridine (2c): ${ }^{[15]}$ White solid $\left(64 \mathrm{mg}, 77 \%\right.$ ), m.p. $69 \sim 71{ }^{\circ} \mathrm{C}$ (lit. ${ }^{[12]}$ m.p. 95 97 $\left.{ }^{\circ} \mathrm{C}\right)$. Eluent: acetone/petroleum ether $(V$ : $V=1: 8), R_{\mathrm{f}}=0.3 .{ }^{1} \mathrm{H}$ NMR $\left(400 \mathrm{MHz}, \mathrm{CDCl}_{3}\right) \delta: 8.30(\mathrm{~d}$, $J=7.0 \mathrm{~Hz}, 1 \mathrm{H}), 7.72(\mathrm{~d}, J=9.1 \mathrm{~Hz}, 1 \mathrm{H}), 7.60$ (d, $J=7.9$ $\mathrm{Hz}, 2 \mathrm{H}), 7.36$ (t, $J=8.0 \mathrm{~Hz}, 1 \mathrm{H}), 7.27$ (d, $J=8.0 \mathrm{~Hz}, 2 \mathrm{H})$, $6.97(\mathrm{t}, J=6.9 \mathrm{~Hz}, 1 \mathrm{H}), 2.41(\mathrm{~s}, 3 \mathrm{H}) ;{ }^{19} \mathrm{~F}$ NMR $(376 \mathrm{MHz}$, $\left.\mathrm{CDCl}_{3}\right) \delta:-57.67 ;{ }^{13} \mathrm{C} \mathrm{NMR}\left(126 \mathrm{MHz}, \mathrm{CDCl}_{3}\right) \delta: 148.3$, $146.2,139.0,130.1,129.6,129.0,127.0,125.6$ (q, $J=3.8$ $\mathrm{Hz}), 122.1$ (q, $J=268.4 \mathrm{~Hz}), 118.1,114.0,109.4$ (q, $J=$ $39.1 \mathrm{~Hz}), 21.5$.

2-(4-Methoxyphenyl)-3-(trifluoromethyl)imidazo[1,2a]pyridine (2d): ${ }^{[15]}$ White solid (63 mg, 72\%), m.p. 99 $101{ }^{\circ} \mathrm{C}$ (lit. ${ }^{[12]}$ m.p. $81 \sim 83{ }^{\circ} \mathrm{C}$ ). Eluent: acetone/petroleum ether $(V: V=1: 10), R_{\mathrm{f}}=0.3 .{ }^{1} \mathrm{H}$ NMR $(400 \mathrm{MHz}$, $\left.\mathrm{CDCl}_{3}\right) \delta: 8.29(\mathrm{~d}, J=6.9 \mathrm{~Hz}, 1 \mathrm{H}), 7.70(\mathrm{~d}, J=9.1 \mathrm{~Hz}$, $1 \mathrm{H}), 7.64(\mathrm{~d}, J=8.4 \mathrm{~Hz}, 2 \mathrm{H}), 7.36(\mathrm{t}, J=8.0 \mathrm{~Hz}, 1 \mathrm{H}), 7.01$ $\sim 6.95(\mathrm{~m}, 3 \mathrm{H}), 3.86(\mathrm{~s}, 3 \mathrm{H}) ;{ }^{19} \mathrm{~F}$ NMR $\left(376 \mathrm{MHz} \mathrm{CDCl}_{3}\right)$ $\delta:-57.67 ;{ }^{13} \mathrm{C}$ NMR $\left(126 \mathrm{MHz}, \mathrm{CDCl}_{3}\right) \delta: 160.4,148.0$, $146.2,131.0,127.0,125.6$ (q, $J=3.6 \mathrm{~Hz}), 125.4,122.1$ (q, $J=268.4 \mathrm{~Hz}), 118.0,113.9,113.8,109.1$ (q, $J=40.3 \mathrm{~Hz})$, 55.42 .

2-(4-(Methylthio)phenyl)-3-(trifluoromethyl)imidazo[1,2-a]pyridine (2e): $:^{[8]}$ White solid (63 mg, 68\%), m.p. $53 \sim 55{ }^{\circ} \mathrm{C}$. Eluent: acetone/petroleum ether $(V: V=1$ : 8), $R_{\mathrm{f}}=0.3 .{ }^{1} \mathrm{H} \mathrm{NMR}\left(400 \mathrm{MHz}, \mathrm{CDCl}_{3}\right) \delta: 8.29(\mathrm{~d}, J=7.0$ $\mathrm{Hz}, 1 \mathrm{H}), 7.71(\mathrm{~d}, J=9.1 \mathrm{~Hz}, 1 \mathrm{H}), 7.62(\mathrm{~d}, J=8.0 \mathrm{~Hz}, 2 \mathrm{H})$, $7.38 \sim 7.30(\mathrm{~m}, 3 \mathrm{H}), 6.97(\mathrm{td}, J=6.9,1.1 \mathrm{~Hz}, 1 \mathrm{H}), 2.52(\mathrm{~s}$, $3 \mathrm{H}) ;{ }^{19} \mathrm{~F} \mathrm{NMR}\left(376 \mathrm{MHz}, \mathrm{CDCl}_{3}\right) \delta$ : $-57.63 ;{ }^{13} \mathrm{C} \mathrm{NMR}$ $\left(126 \mathrm{MHz} \mathrm{CDCl}_{3}\right) \delta: 147.6,146.2,140.0,130.0,129.4$, $127.1,125.9,125.6$ (q, $J=3.8 \mathrm{~Hz}), 122.0$ (q, $J=268.4 \mathrm{~Hz})$, $118.1,114.0,109.4$ (q, $J=39.1 \mathrm{~Hz}), 15.5$.

2-([1,1'-Biphenyl]-4-yl)-3-(trifluoromethyl)imidazo[1,2a]pyridine (2f): $:^{[15]}$ White solid (48 mg, 47\%), m.p. 88 $90{ }^{\circ} \mathrm{C}$ (lit. ${ }^{[12]}$ m.p. $89 \sim 91{ }^{\circ} \mathrm{C}$ ). Eluent: ethyl acetate/petroleum ether $(V: V=1: 3), R_{\mathrm{f}}=0.3 .{ }^{1} \mathrm{H}$ NMR $(400 \mathrm{MHz}$, $\left.\mathrm{CDCl}_{3}\right) \delta: 8.33(\mathrm{~d}, J=7.0 \mathrm{~Hz}, 1 \mathrm{H}), 7.82 \sim 7.65(\mathrm{~m}, 7 \mathrm{H})$, $7.47(\mathrm{t}, J=7.6 \mathrm{~Hz}, 2 \mathrm{H}), 7.42 \sim 7.34(\mathrm{~m}, 2 \mathrm{H}), 7.00(\mathrm{td}, J=$ 6.9, $1.0 \mathrm{~Hz}, 1 \mathrm{H}) ;{ }^{19} \mathrm{~F}$ NMR $\left(376 \mathrm{MHz}, \mathrm{CDCl}_{3}\right) \delta$ : -57.58 ; ${ }^{13} \mathrm{C}$ NMR $\left(126 \mathrm{MHz}, \mathrm{CDCl}_{3}\right) \delta: 147.8,146.3,141.8,140.7$, $131.9,130.1,128.9,127.7,127.3,127.1,127.0,125.6(\mathrm{q}$, $J=3.8 \mathrm{~Hz}), 122.1(\mathrm{q}, J=268.4 \mathrm{~Hz}), 118.2,114.1,109.7(\mathrm{q}$, $J=40.3 \mathrm{~Hz})$.

2-(Naphthalen-1-yl)-3-(trifluoromethyl)imidazo[1,2a]pyridine (2g): ${ }^{[14]}$ Yellow oil $(34 \mathrm{mg}, 36 \%)$. Eluent: acetone/petroleum ether $(V: V=1: 10), R_{\mathrm{f}}=0.2 .{ }^{1} \mathrm{H}$ NMR $\left(400 \mathrm{MHz} \mathrm{CDCl}_{3}\right) \delta: 8.37(\mathrm{~d}, J=6.9 \mathrm{~Hz}, 1 \mathrm{H}), 7.94(\mathrm{q}, J=$ $9.3 \mathrm{~Hz}, 2 \mathrm{H}), 7.81$ (q, $J=8.0 \mathrm{~Hz}, 2 \mathrm{H}), 7.60 \sim 7.52(\mathrm{~m}, 2 \mathrm{H})$, $7.52 \sim 7.42(\mathrm{~m}, 3 \mathrm{H}), 7.06(\mathrm{td}, J=6.9,0.9 \mathrm{~Hz}, 1 \mathrm{H}) ;{ }^{19} \mathrm{~F}$ NMR $\left(376 \mathrm{MHz}, \mathrm{CDCl}_{3}\right) \delta:-58.83 ;{ }^{13} \mathrm{C}$ NMR $(126$ 
$\left.\mathrm{MHz}, \mathrm{CDCl}_{3}\right) \delta: 146.8,146.3,133.6,132.3,130.5,129.5$, $128.6,128.3,127.2,126.7,126.1,125.8,125.5(\mathrm{q}, J=3.8$ $\mathrm{Hz}), 125.0,122.8$ (q, $J=268.4 \mathrm{~Hz}), 118.3,114.2 .111 .8$ (q, $J=39.1 \mathrm{~Hz})$.

2-(9H-Fluoren-2-yl)-3-(trifluoromethyl)imidazo[1,2a]pyridine (2h): White solid (67 mg, 64\%), m.p. 133 $125{ }^{\circ} \mathrm{C}$. Eluent: acetone/petroleum ether $(V: V=1: 7)$, $R_{\mathrm{f}}=0.2 .{ }^{1} \mathrm{H} \mathrm{NMR}\left(400 \mathrm{MHz}, \mathrm{CDCl}_{3}\right) \delta: 8.33(\mathrm{~d}, J=6.7$ $\mathrm{Hz}, 1 \mathrm{H}), 7.91$ (s, 1H), 7.86 (q, $J=6.7 \mathrm{~Hz}, 2 \mathrm{H}), 7.73$ (q, $J=$ $8.0 \mathrm{~Hz}, 2 \mathrm{H}), 7.57(\mathrm{~d}, J=7.4 \mathrm{~Hz}, 1 \mathrm{H}), 7.40(\mathrm{t}, J=8.0 \mathrm{~Hz}$, 2H), $7.34(\mathrm{td}, J=7.4,1.2 \mathrm{~Hz}, 1 \mathrm{H}), 7.00(\mathrm{td}, J=6.9,1.1 \mathrm{~Hz}$, 1H), $3.98(\mathrm{~s}, 2 \mathrm{H}) ;{ }^{19} \mathrm{~F}$ NMR $\left(376 \mathrm{MHz}, \mathrm{CDCl}_{3}\right) \delta$ : $-57.57 ;{ }^{13} \mathrm{C}$ NMR $\left(126 \mathrm{MHz}, \mathrm{CDCl}_{3}\right) \delta: 148.5,146.2$, $143.9,143.4,142.6,141.3,131.3,128.6,127.2,127.1$, $127.0,126.3,125.7$ (q, $J=3.8 \mathrm{~Hz}), 125.2,122.0$ (q, $J=$ $268.4 \mathrm{~Hz}$ ), 120.4, 119.7, 118.1, 114.1, 109.6 (q, $J=39.1$ $\mathrm{Hz}$ ), 37.1; MS (EI) $m / z: 350\left[\mathrm{M}^{+}\right]$; HRMS (EI) calcd for $\mathrm{C}_{21} \mathrm{H}_{13} \mathrm{~F}_{3} \mathrm{~N}_{2} 350.1025$, found 350.1030 .

2-(Thiophen-2-yl)-3-(trifluoromethyl)imidazo[1,2-a]pyridine (2i): ${ }^{[15]}$ White solid $(39 \mathrm{mg}, 63 \%)$, m.p. $74 \sim 71{ }^{\circ} \mathrm{C}$. Eluent: acetone/petroleum ether $(V: V=1: 10), \quad R_{\mathrm{f}}=$ 0.2. ${ }^{1} \mathrm{H} \mathrm{NMR}\left(400 \mathrm{MHz}, \mathrm{CDCl}_{3}\right) \delta: 8.29(\mathrm{~d}, J=7.0 \mathrm{~Hz}$, $1 \mathrm{H}), 7.70(\mathrm{~d}, J=8.0 \mathrm{~Hz}, 1 \mathrm{H}), 7.50 \sim 7.49(\mathrm{~m}, 1 \mathrm{H}), 7.46(\mathrm{~d}$, $J=4.0 \mathrm{~Hz}, 1 \mathrm{H}), 7.36(\mathrm{t}, J=8.0 \mathrm{~Hz}, 1 \mathrm{H}), 7.13(\mathrm{t}, J=4.0$ $\mathrm{Hz}, 1 \mathrm{H}), 6.96(\mathrm{t}, J=6.0 \mathrm{~Hz}, 1 \mathrm{H}) ;{ }^{19} \mathrm{~F}$ NMR $(376 \mathrm{MHz}$, $\left.\mathrm{CDCl}_{3}\right) \delta$ : $-57.62 ;{ }^{13} \mathrm{C} \mathrm{NMR}\left(126 \mathrm{MHz}, \mathrm{CDCl}_{3}\right) \delta: 146.0$, $141.6,134.9,128.2$ (q, $J=3.8 \mathrm{~Hz}$ ), 128.0, 127.9, 127.3, 125.6 (q, $J=3.8 \mathrm{~Hz}), 122.0$ (q, $J=268.4 \mathrm{~Hz}), 118.9,114.2$, $108.5(\mathrm{q}, J=40.3 \mathrm{~Hz})$.

2-(4-Fluorophenyl)-3-(trifluoromethyl)imidazo[1,2-a]pyridine $(\mathbf{2} \mathbf{j})::^{[15]}$ White solid $(61 \mathrm{mg}, 72 \%)$, m.p. 63 $65{ }^{\circ} \mathrm{C}$ (lit. ${ }^{[12]}$ m.p. $55 \sim 57{ }^{\circ} \mathrm{C}$ ). Eluent: acetone/petroleum ether $(V: V=1: 8), R_{\mathrm{f}}=0.4 .{ }^{1} \mathrm{H}$ NMR $\left(400 \mathrm{MHz}, \mathrm{CDCl}_{3}\right)$ $\delta: 8.30(\mathrm{~d}, J=6.9 \mathrm{~Hz}, 1 \mathrm{H}), 7.74 \sim 7.63(\mathrm{~m}, 3 \mathrm{H}), 7.42 \sim$ $7.35(\mathrm{~m}, 1 \mathrm{H}), 7.18 \sim 7.10(\mathrm{~m}, 2 \mathrm{H}), 6.99(\mathrm{td}, J=6.9,1.0 \mathrm{~Hz}$, $1 \mathrm{H}) ;{ }^{19} \mathrm{~F}$ NMR $\left(376 \mathrm{MHz}, \mathrm{CDCl}_{3}\right) \delta$ : $-57.75,-112.55$; ${ }^{13} \mathrm{C} \mathrm{NMR}\left(126 \mathrm{MHz}, \mathrm{CDCl}_{3}\right) \delta: 164.4,162.4,147.1$ (d, $J=$ $1.3 \mathrm{~Hz}), 146.2,131.5$ (d, $J=7.6 \mathrm{~Hz}), 129.1$ (d, $J=2.5 \mathrm{~Hz})$, $127.3,125.6$ (q, $J=3.8 \mathrm{~Hz}), 122.0$ (q, $J=268.4 \mathrm{~Hz}), 118.1$, 115.4 (d, $J=21.4 \mathrm{~Hz}), 114.2,109.6$ (q, $J=40.3 \mathrm{~Hz})$.

2-(4-Chlorophenyl)-3-(trifluoromethyl)imidazo[1,2-a]pyridine (2k): ${ }^{[15]}$ White solid $(60 \mathrm{mg}, 67 \%)$, m.p. 86 $88{ }^{\circ} \mathrm{C}$ (lit. ${ }^{[12]}$ m.p. $84 \sim 86{ }^{\circ} \mathrm{C}$ ). Eluent: acetone/petroleum ether $(V: V=1: 10), R_{\mathrm{f}}=0.4 .{ }^{1} \mathrm{H} \mathrm{NMR}(400 \mathrm{MHz}$, $\left.\mathrm{CDCl}_{3}\right) \delta: 8.30(\mathrm{~d}, J=6.9 \mathrm{~Hz}, 1 \mathrm{H}), 7.72(\mathrm{~d}, J=9.1 \mathrm{~Hz}$, $1 \mathrm{H}), 7.63(\mathrm{~d}, J=8.2 \mathrm{~Hz}, 2 \mathrm{H}), 7.44 \sim 7.37(\mathrm{~m}, 3 \mathrm{H}), 6.99$ (td, $J=6.9,1.0 \mathrm{~Hz}, 1 \mathrm{H}) ;{ }^{19} \mathrm{~F}$ NMR $\left(376 \mathrm{MHz}, \mathrm{CDCl}_{3}\right) \delta$ : $-57.71 ;{ }^{13} \mathrm{C}$ NMR $\left(126 \mathrm{MHz}, \mathrm{CDCl}_{3}\right) \delta: 146.9,146.3$, $135.3,131.5,131.0,128.6,127.3,125.6$ (q, $J=3.8 \mathrm{~Hz}$ ), $121.9(\mathrm{q}, J=268.4 \mathrm{~Hz}), 118.2,114.3,109.7$ (q, $J=40.3$ $\mathrm{Hz})$.

2-(4-Bromophenyl)-3-(trifluoromethyl)imidazo[1,2-a]pyridine (2l): ${ }^{[15]}$ White solid (71 mg, 69\%), m.p. 94 $96{ }^{\circ} \mathrm{C}$ (lit. ${ }^{[12]}$ m.p. $94 \sim 96{ }^{\circ} \mathrm{C}$ ). Eluent: ethyl acetate/petro- leum ether $(V: V=1: 2), R_{\mathrm{f}}=0.3$. ${ }^{1} \mathrm{H}$ NMR $\left(400 \mathrm{MHz}, \mathrm{CDCl}_{3}\right) \delta: 8.29(\mathrm{~d}, J=7.0 \mathrm{~Hz}, 1 \mathrm{H}), 7.71(\mathrm{~d}, J=$ $9.1 \mathrm{~Hz}, 1 \mathrm{H}), 7.60 \sim 7.55(\mathrm{~m}, 4 \mathrm{H}), 7.40 \sim 7.36(\mathrm{~m}, 1 \mathrm{H}), 6.99$ $(\mathrm{td}, J=6.9,1.1 \mathrm{~Hz}, 1 \mathrm{H}) ;{ }^{19} \mathrm{~F} \mathrm{NMR}\left(376 \mathrm{MHz}, \mathrm{CDCl}_{3}\right) \delta$ : -57.69; ${ }^{13} \mathrm{C}$ NMR $\left(126 \mathrm{MHz}, \mathrm{CDCl}_{3}\right) \delta: 146.9,146.3$, $131.9,131.5,131.3,127.3,125.6$ (q, $J=3.8 \mathrm{~Hz}$ ), 123.6, $121.9(\mathrm{q}, J=268.4 \mathrm{~Hz}), 118.2,114.3,109.7$ (q, $J=40.3$ $\mathrm{Hz})$.

2-(4-Iodophenyl)-3-(trifluoromethyl)imidazo[1,2-a]pyridine (2m): ${ }^{[15]}$ White solid (83 mg, 71\%), m.p. 76 $78{ }^{\circ} \mathrm{C}$ (lit. ${ }^{[9]}$ m.p. $78 \sim 79{ }^{\circ} \mathrm{C}$ ). Eluent: ethyl acetate/petroleum ether $(V: V=1: 2), R_{\mathrm{f}}=0.3$. ${ }^{1} \mathrm{H}$ NMR $(400 \mathrm{MHz}$, $\left.\mathrm{CDCl}_{3}\right) \delta: 8.30(\mathrm{~d}, J=7.0 \mathrm{~Hz}, 1 \mathrm{H}), 7.79(\mathrm{~d}, J=8.5 \mathrm{~Hz}$, 2H), $7.72(\mathrm{~d}, J=9.1 \mathrm{~Hz}, 1 \mathrm{H}), 7.43(\mathrm{~d}, J=8.4 \mathrm{~Hz}, 2 \mathrm{H})$, $7.41 \sim 7.35(\mathrm{~m}, 1 \mathrm{H}), 7.00(\mathrm{t}, J=6.9 \mathrm{~Hz}, 1 \mathrm{H}) ;{ }^{19} \mathrm{~F}$ NMR $\left(376 \mathrm{MHz}, \mathrm{CDCl}_{3}\right) \delta$ : $-57.67 ;{ }^{13} \mathrm{C} \mathrm{NMR}(126 \mathrm{MHz}$, $\left.\mathrm{CDCl}_{3}\right) \delta: 147.0,146.3,137.5,132.5,131.4,127.3,125.6$ (q, $J=3.8 \mathrm{~Hz}), 121.9$ (q, $J=268.4 \mathrm{~Hz}), 118.2,114.3,109.7$ (q, $J=40.3 \mathrm{~Hz}), 95.5$.

4-(3-(Trifluoromethyl)imidazo[1,2-a]pyridin-2-yl)benzonitrile (2n): ${ }^{[8]}$ White solid $(43 \mathrm{mg}, 66 \%)$, m.p. 165 $166{ }^{\circ} \mathrm{C}$ (lit. ${ }^{[12]}$ m.p. $147 \sim 148{ }^{\circ} \mathrm{C}$ ). Eluent: acetone/petroleum ether $(V: V=1: 10), R_{\mathrm{f}}=0.2 .{ }^{1} \mathrm{H}$ NMR $(400 \mathrm{MHz}$, $\left.\mathrm{CDCl}_{3}\right) \delta: 8.33(\mathrm{~d}, J=7.0 \mathrm{~Hz}, 1 \mathrm{H}), 7.81(\mathrm{~d}, J=8.1 \mathrm{~Hz}$, 2H), $7.76(\mathrm{~s}, 1 \mathrm{H}), 7.75(\mathrm{~d}, J=8.5 \mathrm{~Hz}, 2 \mathrm{H}), 7.47 \sim 7.41(\mathrm{~m}$, 1H), 7.05 (t, $J=6.0 \mathrm{~Hz}, 1 \mathrm{H}) ;{ }^{19} \mathrm{~F}$ NMR $\left(376 \mathrm{MHz}, \mathrm{CDCl}_{3}\right)$ $\delta$ : $-57.67 ;{ }^{13} \mathrm{C} \mathrm{NMR}\left(126 \mathrm{MHz}, \mathrm{CDCl}_{3}\right) \delta: 146.4,145.9$, 137.6, 132.1, 130.4, 127.7, 125.7 (q, $J=2.9 \mathrm{~Hz}), 121.7$ (q, $J=267.1 \mathrm{~Hz}), 118.8,118.4,114.7,112.8,110.4$ (q, $J=$ $40.3 \mathrm{~Hz})$.

Methyl 4-(3-(trifluoromethyl)imidazo[1,2-a]pyridin-2yl)benzoate (2o): White solid (44 mg, 46\%), m.p. 99 $101{ }^{\circ} \mathrm{C}$. Eluent: acetone/petroleum ether $(V: V=1: 10)$, $R_{\mathrm{f}}=0.3 .{ }^{1} \mathrm{H}$ NMR $\left(400 \mathrm{MHz}, \mathrm{CDCl}_{3}\right) \delta: 8.32(\mathrm{~d}, J=7.0$ $\mathrm{Hz}, 1 \mathrm{H}), 8.13(\mathrm{~d}, J=8.3 \mathrm{~Hz}, 2 \mathrm{H}), 7.80 \sim 7.72(\mathrm{~m}, 3 \mathrm{H})$, $7.42(\mathrm{t}, J=8.0 \mathrm{~Hz}, 1 \mathrm{H}), 7.03(\mathrm{t}, J=6.0 \mathrm{~Hz}, 1 \mathrm{H}), 3.95(\mathrm{~s}$, $3 \mathrm{H}) ;{ }^{19} \mathrm{~F}$ NMR $\left(376 \mathrm{MHz}, \mathrm{CDCl}_{3}\right) \delta:-57.69 ;{ }^{13} \mathrm{C} \mathrm{NMR}$ $\left(126 \mathrm{MHz}, \mathrm{CDCl}_{3}\right) \delta: 167.0,146.9,146.4,137.4,130.6$, 129.8, 129.6, 127.5, 125.7 (q, $J=3.7 \mathrm{~Hz}), 121.8$ (q, $J=$ $268.4 \mathrm{~Hz}), 118.3,114.4,110.2$ (q, $J=38.2 \mathrm{~Hz}$ ), 52.4; MS (EI) $m / z: 320\left[\mathrm{M}^{+}\right]$; HRMS (EI) calcd for $\mathrm{C}_{16} \mathrm{H}_{11} \mathrm{~F}_{3} \mathrm{~N}_{2} \mathrm{O}_{2}$ 320.0767 , found 320.0764 .

2-(3-Methoxyphenyl)-3-(trifluoromethyl)imidazo[1,2a]pyridine (2p): ${ }^{[15]}$ White solid (54 mg, 62\%), m.p. 82 $83{ }^{\circ} \mathrm{C}$. Eluent: acetone/petroleum ether $(V: V=1: 8)$, $R_{\mathrm{f}}=0.3 .{ }^{1} \mathrm{H}$ NMR $\left(400 \mathrm{MHz}, \mathrm{CDCl}_{3}\right) \delta: 8.31(\mathrm{~d}, J=7.0$ $\mathrm{Hz}, 1 \mathrm{H}), 7.73(\mathrm{~d}, J=9.1 \mathrm{~Hz}, 1 \mathrm{H}), 7.41(\mathrm{t}, J=7.6 \mathrm{~Hz}, 1 \mathrm{H})$, $7.37(\mathrm{t}, J=7.6 \mathrm{~Hz}, 1 \mathrm{H}), 7.28 \sim 7.24(\mathrm{~m}, 2 \mathrm{H}), 7.04 \sim 6.96$ $(\mathrm{m}, 2 \mathrm{H}), 3.86(\mathrm{~s}, 3 \mathrm{H}) ;{ }^{19} \mathrm{~F}$ NMR $\left(376 \mathrm{MHz}, \mathrm{CDCl}_{3}\right) \delta$ : $-57.59 ;{ }^{13} \mathrm{C}$ NMR $\left(126 \mathrm{MHz}, \mathrm{CDCl}_{3}\right) \delta: 159.5,148.0$, $146.2,134.2,129.3,127.1,125.6$ (q, $J=3.8 \mathrm{~Hz}$ ), 122.3, 122.0 (q, $J=268.4 \mathrm{~Hz}$ ), 118.2, 115.3, 114.8, 114.1, 109.7 (q, $J=40.3 \mathrm{~Hz}), 55.46$.

2-(3-Bromophenyl)-3-(trifluoromethyl)imidazo[1,2- $a$ ]pyridine (2q) $:^{[15]}$ White solid $(67 \mathrm{mg}, 65 \%)$, m.p. $73 \sim$ $75{ }^{\circ} \mathrm{C}$. Eluent: ethyl acetate/petroleum ether $(V: V=1$ : 3), $R_{\mathrm{f}}=0.4 .{ }^{1} \mathrm{H}$ NMR (400 MHz, $\left.\mathrm{CDCl}_{3}\right) \delta: 8.31(\mathrm{~d}, J=6.9$ $\mathrm{Hz}, 1 \mathrm{H}), 7.87(\mathrm{~s}, 1 \mathrm{H}), 7.73(\mathrm{~d}, J=9.1 \mathrm{~Hz}, 1 \mathrm{H}), 7.61 \sim 7.56$ $(\mathrm{m}, 2 \mathrm{H}), 7.41(\mathrm{t}, J=8.0 \mathrm{~Hz}, 1 \mathrm{H}), 7.33(\mathrm{t}, J=7.9 \mathrm{~Hz}, 1 \mathrm{H})$, 7.02 (t, $J=6.9 \mathrm{~Hz}, 1 \mathrm{H}) ;{ }^{19} \mathrm{~F}$ NMR $\left(376 \mathrm{MHz}, \mathrm{CDCl}_{3}\right) \delta$ : 
-57.73; ${ }^{13} \mathrm{C}$ NMR $\left(126 \mathrm{MHz}, \mathrm{CDCl}_{3}\right) \delta: 146.5,146.3$, $135.0,132.6,132.1,129.8,128.4,127.4,125.7$ (q, $J=3.8$ $\mathrm{Hz}), 122.4,121.8$ (q, $J=268.4 \mathrm{~Hz}), 118.3,114.4,110.0$ (q, $J=40.3 \mathrm{~Hz}$ ).

8-Methyl-2-phenyl-3-(trifluoromethyl)imidazo[1,2-a]pyridine (2r): $:^{[15]}$ Yellow oil (43 mg, 53\%). Eluent: acetone/petroleum ether $(V: V=1: 8), R_{\mathrm{f}}=0.3 .{ }^{1} \mathrm{H} \mathrm{NMR}$ $\left(400 \mathrm{MHz}, \mathrm{CDCl}_{3}\right) \delta: 8.17(\mathrm{~d}, J=6.9 \mathrm{~Hz}, 1 \mathrm{H}), 7.70(\mathrm{~d}, J=$ $6.7 \mathrm{~Hz}, 2 \mathrm{H}), 7.50 \sim 7.40(\mathrm{~m}, 3 \mathrm{H}), 7.16(\mathrm{~d}, J=6.9 \mathrm{~Hz}, 1 \mathrm{H})$, $6.89(\mathrm{t}, J=6.9 \mathrm{~Hz}, 1 \mathrm{H}), 2.68(\mathrm{~s}, 3 \mathrm{H}) ;{ }^{19} \mathrm{~F} \mathrm{NMR}(376 \mathrm{MHz}$, $\left.\mathrm{CDCl}_{3}\right) \delta:-57.83 ;{ }^{13} \mathrm{C} \mathrm{NMR}\left(126 \mathrm{MHz}, \mathrm{CDCl}_{3}\right) \delta: 147.6$, $146.6,133.3,129.8,128.9,128.3,128.3,125.7,123.3$ (q, $J=3.8 \mathrm{~Hz}), 122.1(\mathrm{q}, J=268.4 \mathrm{~Hz}), 114.0,110.0(\mathrm{q}, J=$ 40.3 Hz), 17.3.

7-Methyl-2-phenyl-3-(trifluoromethyl)imidazo[1,2a]pyridine (2s): ${ }^{[15]}$ White solid (61 mg, 73\%), m.p. 98 $100{ }^{\circ} \mathrm{C}$ (lit. ${ }^{[12]}$ m.p. $76 \sim 78{ }^{\circ} \mathrm{C}$ ). Eluent: acetone/petroleum ether $(V: V=1: 8), R_{\mathrm{f}}=0.2 .{ }^{1} \mathrm{H}$ NMR $(400 \mathrm{MHz}$, $\left.\mathrm{CDCl}_{3}\right) \delta: 8.16(\mathrm{~d}, J=7.1 \mathrm{~Hz}, 1 \mathrm{H}), 7.68(\mathrm{~d}, J=7.0 \mathrm{~Hz}$, $2 \mathrm{H}), 7.41 \sim 7.46(\mathrm{~m}, 4 \mathrm{H}), 6.80(\mathrm{dd}, J=8.0,4.0 \mathrm{~Hz}, 1 \mathrm{H})$, $2.43(\mathrm{~s}, 3 \mathrm{H}) ;{ }^{19} \mathrm{~F}$ NMR $\left(376 \mathrm{MHz}, \mathrm{CDCl}_{3}\right) \delta:-57.52 ;{ }^{13} \mathrm{C}$ NMR $\left(126 \mathrm{MHz}, \mathrm{CDCl}_{3}\right) \delta: 148.0,146.7,138.4,133.1$, $129.6,128.9,128.2,124.7$ (q, $J=3.8 \mathrm{~Hz}), 122.1$ (q, $J=$ $268.4 \mathrm{~Hz}$ ), 116.6, 116.5, 109.0 (q, $J=40.3 \mathrm{~Hz}), 21.4$.

7-Chloro-2-phenyl-3-(trifluoromethyl)imidazo[1,2-a]pyridine (2t) ${ }^{[15]}$ White solid $(41 \mathrm{mg}, 46 \%)$, m.p. 123 $125{ }^{\circ} \mathrm{C} \quad$ (lit. ${ }^{[12]}$ m.p. $85 \sim 87{ }^{\circ} \mathrm{C}$ ). Eluent: acetone/petroleum ether $(V: V=1: 8), R_{\mathrm{f}}=0.4 .{ }^{1} \mathrm{H} \mathrm{NMR}$ $\left(400 \mathrm{MHz}, \mathrm{CDCl}_{3}\right) \delta: 8.34(\mathrm{~s}, 1 \mathrm{H}), 7.68 \sim 7.66(\mathrm{~m}, 3 \mathrm{H})$, $7.48 \sim 7.45(\mathrm{~m}, 3 \mathrm{H}), 7.35(\mathrm{dd}, J=9.6,1.8 \mathrm{~Hz}, 1 \mathrm{H}) ;{ }^{19} \mathrm{~F}$ NMR $\left(376 \mathrm{MHz}, \mathrm{CDCl}_{3}\right) \delta:-57.72 ;{ }^{13} \mathrm{C}$ NMR $(126$ $\left.\mathrm{MHz}, \mathrm{CDCl}_{3}\right) \delta: 148.9,144.5,132.5,129.6,129.3,128.6$, 128.4, 125.7 (q, $J=3.8 \mathrm{~Hz}), 122.43,121.7$ (q, $J=268.4$ $\mathrm{Hz}), 118.5,110.2$ (q, $J=40.3 \mathrm{~Hz})$.

7-Bromo-2-phenyl-3-(trifluoromethyl)imidazo[1,2-a]pyridine (2u): ${ }^{[15]}$ White solid (53 mg, 54\%), m.p. 73 $75{ }^{\circ} \mathrm{C}$ (lit. ${ }^{[9]}$ m.p. $81 \sim 82{ }^{\circ} \mathrm{C}$ ). Eluent: acetone/petroleum ether $(V: V=1: 8), R_{\mathrm{f}}=0.4 .{ }^{1} \mathrm{H} \mathrm{NMR}\left(400 \mathrm{MHz}, \mathrm{CDCl}_{3}\right)$ $\delta: 8.44(\mathrm{~s}, 1 \mathrm{H}), 7.68(\mathrm{~d}, J=5.3 \mathrm{~Hz}, 2 \mathrm{H}), 7.62(\mathrm{~d}, J=9.5$ $\mathrm{Hz}, 1 \mathrm{H}), 7.43 \sim 7.49(\mathrm{~m}, 4 \mathrm{H}) ;{ }^{19} \mathrm{~F} \mathrm{NMR}\left(376 \mathrm{MHz}, \mathrm{CDCl}_{3}\right)$ $\delta:-57.63 ;{ }^{13} \mathrm{C} \mathrm{NMR}\left(126 \mathrm{MHz}, \mathrm{CDCl}_{3}\right) \delta: 148.7,144.6$, $132.4,130.7,129.6,129.3,128.4,125.7$ (q, $J=3.8 \mathrm{~Hz}$ ), $121.7(\mathrm{q}, J=268.4 \mathrm{~Hz}), 118.7,110.0(\mathrm{q}, J=40.3 \mathrm{~Hz})$, 108.9 .

6-Methoxy-2-phenyl-3-(trifluoromethyl)imidazo[1,2a]pyridine (2v): ${ }^{[15]}$ White solid (35 mg, 40\%), m.p. $110 \sim$ $112{ }^{\circ} \mathrm{C}$ (lit. ${ }^{[9]}$ m.p. $109 \sim 111{ }^{\circ} \mathrm{C}$ ). Eluent: acetone/petroleum ether $(V: V=1: 8), R_{\mathrm{f}}=0.3 .{ }^{1} \mathrm{H}$ NMR $(400 \mathrm{MHz}$, $\left.\mathrm{CDCl}_{3}\right) \delta: 7.77(\mathrm{~s}, 1 \mathrm{H}), 7.67(\mathrm{~d}, J=7.0 \mathrm{~Hz}, 2 \mathrm{H}), 7.61$ (d, $J=9.8 \mathrm{~Hz}, 1 \mathrm{H}), 7.47 \sim 7.47(\mathrm{~m}, 3 \mathrm{H}), 7.17(\mathrm{dd}, J=9.8,1.9$ $\mathrm{Hz}, 1 \mathrm{H}), 3.87$ (s, 3H); ${ }^{19} \mathrm{~F} \mathrm{NMR}\left(376 \mathrm{MHz}, \mathrm{CDCl}_{3}\right) \delta:-$ $58.10 ;{ }^{13} \mathrm{C}$ NMR $\left(126 \mathrm{MHz}, \mathrm{CDCl}_{3}\right) \delta: 150.2,147.9,143.3$, $133.2,129.6,128.9,128.3,122.3,122.1$ (q, $J=268.4 \mathrm{~Hz}$ ), 118.2, 110.4 (q, $J=39.1 \mathrm{~Hz}), 107.5$ (q, $J=3.8 \mathrm{~Hz}), 56.4$.

Methyl 2-phenyl-3-(trifluoromethyl)imidazo[1,2-a]pyridine-7-carboxylate (2w). White solid (48 mg, 50\%). m.p. $125 \sim 127{ }^{\circ} \mathrm{C}$. Eluent: acetone/petroleum ether $(V: V=$
$1: 8), R_{\mathrm{f}}=0.3 .{ }^{1} \mathrm{H}$ NMR $\left(400 \mathrm{MHz}, \mathrm{CDCl}_{3}\right) \delta: 8.42(\mathrm{~s}$, $1 \mathrm{H}), 8.35(\mathrm{~d}, J=7.2 \mathrm{~Hz}, 1 \mathrm{H}), 7.70 \sim 7.69(\mathrm{~m}, 2 \mathrm{H}), 7.58$ (dd, $J=7.2,1.5 \mathrm{~Hz}, 1 \mathrm{H}), 7.48 \sim 7.46(\mathrm{~m}, 3 \mathrm{H}), 3.99$ (s, 3H); ${ }^{19} \mathrm{~F}$ NMR $\left(376 \mathrm{MHz}, \mathrm{CDCl}_{3}\right) \delta$ : $-57.70 ;{ }^{13} \mathrm{C}$ NMR $(126$ $\left.\mathrm{MHz}, \mathrm{CDCl}_{3}\right) \delta: 165.1,149.9,145.3,132.5,129.7,129.4$, 128.6, 128.4, 125.4 (q, $J=3.8 \mathrm{~Hz}), 121.7$ (q, $J=268.4 \mathrm{~Hz}$ ), 120.5, 113.3, 111.1 (q, $J=40.3 \mathrm{~Hz}), 53.0$; MS (FI) $\mathrm{m} / \mathrm{z}$ : $320\left[\mathrm{M}^{+}\right]$; HRMS (FI) calcd for $\mathrm{C}_{16} \mathrm{H}_{11} \mathrm{~F}_{3} \mathrm{~N}_{2} \mathrm{O}_{2} 320.0767$, found 320.0774 .

6-Chloro-2-methyl-3-(trifluoromethyl)imidazo[1,2-a]pyridine (2x): White solid (28 mg, 40\%), m.p. 84 87 ${ }^{\circ} \mathrm{C}$. Eluent: ethyl acetate/petroleum ether $(V: V=1: 4), R_{\mathrm{f}}=$ 0.4. ${ }^{1} \mathrm{H}$ NMR (400 MHz, $\left.\mathrm{CDCl}_{3}\right) \delta: 8.20(\mathrm{~s}, 1 \mathrm{H}), 7.54(\mathrm{~d}$, $J=9.5 \mathrm{~Hz}, 1 \mathrm{H}), 7.29(\mathrm{dd}, J=9.6,1.8 \mathrm{~Hz}, 1 \mathrm{H}), 2.57 \sim 2.56$ $(\mathrm{m}, 3 \mathrm{H}) ;{ }^{19} \mathrm{~F}$ NMR $\left(376 \mathrm{MHz}, \mathrm{CDCl}_{3}\right) \delta:-59.30 ;{ }^{13} \mathrm{C}$ NMR (126 MHz, $\left.\mathrm{CDCl}_{3}\right) \delta: 146.4,144.3,128.1,123.0$ (q, $J=3.8 \mathrm{~Hz}), 122.0(\mathrm{q}, J=267.1 \mathrm{~Hz}), 122.0,117.8,110.8(\mathrm{q}$, $J=39.1 \mathrm{~Hz}$ ), 14.7; MS (EI) $m / z: 234\left[\mathrm{M}^{+}\right]$; HRMS (EI) calcd for $\mathrm{C}_{9} \mathrm{H}_{6} \mathrm{ClF}_{3} \mathrm{~N}_{2} \mathrm{O}_{2} 234.0166$, found 234.0162.

6-(4-Bromophenyl)-5-(trifluoromethyl)imidazo[2,1-b]thiazole (2y): White solid (68 mg, 65\%), m.p. 112 $114{ }^{\circ} \mathrm{C}$. Eluent: acetone/petroleum ether $(V: V=1: 8)$, $R_{\mathrm{f}}=0.3 .{ }^{1} \mathrm{H}$ NMR $\left(400 \mathrm{MHz}, \mathrm{CDCl}_{3}\right) \delta: 7.59 \sim 7.57(\mathrm{~m}$, $5 \mathrm{H}), 7.01(\mathrm{~d}, J=4.5 \mathrm{~Hz}, 1 \mathrm{H}) ;{ }^{19} \mathrm{~F} \mathrm{NMR}\left(376 \mathrm{MHz}, \mathrm{CDCl}_{3}\right)$ $\delta$ : $-56.37 ;{ }^{13} \mathrm{C} \mathrm{NMR}\left(126 \mathrm{MHz}, \mathrm{CDCl}_{3}\right) \delta: 151.7,147.9$, $131.7,131.6,130.4,123.4,121.6$ (q, $J=268.4 \mathrm{~Hz}), 119.0$ (q, $J=2.5 \mathrm{~Hz}), 114.7,111.9$ (q, $J=40.3 \mathrm{~Hz}) . \mathrm{MS}(\mathrm{EI}): 346$ $\left[\mathrm{M}^{+}\right]$; HRMS (EI) calcd for $\mathrm{C}_{12} \mathrm{H}_{6} \mathrm{BrF}_{3} \mathrm{~N}_{2} \mathrm{~S}$ 345.9382, found 345.9388 .

2-(4-(Methylsulfonyl)phenyl)-3-(trifluoromethyl)imidazo[1,2-a]pyridine (3): ${ }^{[15]}$ White solid (42 mg, 43\%), m.p. $157 \sim 159{ }^{\circ} \mathrm{C}$. Eluent: ethyl acetate/petroleum ether $(V$ : $V=2: 1), R_{\mathrm{f}}=0.3 .{ }^{1} \mathrm{H}$ NMR $\left(400 \mathrm{MHz}, \mathrm{CDCl}_{3}\right) \delta: 8.34(\mathrm{~d}$, $J=6.8 \mathrm{~Hz}, 1 \mathrm{H}), 8.04(\mathrm{~d}, J=8.2 \mathrm{~Hz}, 2 \mathrm{H}), 7.91(\mathrm{~d}, J=8.1$ $\mathrm{Hz}, 2 \mathrm{H}), 7.77$ (d, $J=9.0 \mathrm{~Hz}, 1 \mathrm{H}), 7.45(\mathrm{t}, J=8.0 \mathrm{~Hz}, 1 \mathrm{H})$, $7.07(\mathrm{t}, J=6.8 \mathrm{~Hz}, 1 \mathrm{H}), 3.10(\mathrm{~s}, 3 \mathrm{H}) ;{ }^{19} \mathrm{~F} \mathrm{NMR}(376 \mathrm{MHz}$, $\left.\mathrm{CDCl}_{3}\right) \delta:-57.65 ;{ }^{13} \mathrm{C} \mathrm{NMR}\left(126 \mathrm{MHz}, \mathrm{CDCl}_{3}\right) \delta: 146.5$, $145.8,140.8,138.5,130.7,127.8,127.4,125.7$ (q, $J=3.4$ $\mathrm{Hz}), 122.0(\mathrm{q}, J=268.0 \mathrm{~Hz}), 118.4,114.8,110.5$ (q, $J=$ $40.3 \mathrm{~Hz}), 44.7$.

Supporting Information ${ }^{1} \mathrm{H}$ NMR, ${ }^{19} \mathrm{~F}$ NMR and ${ }^{13} \mathrm{C}$ NMR of compounds $\mathbf{2} \mathbf{a} \sim \mathbf{2 y}$ and $\mathbf{3}$. The Supporting Information is available free of charge via the Internet at http:// sioc-journal.cn/.

\section{References}

[1] (a) Krause, M.; Foks, H.; Gobis, K. Molecules 2017, 22, 399, doi: 10.3390/molecules22030399.

(b) Bagdi, A. K.; Santra, S.; Monir, K.; Hajra, A. Chem. Commun. 2015, 51, 1555.

[2] Zivkovic, B.; Morel, E.; Joly, D.; Perrault, G.; Sanger, D. J.; Lloyd, K. G. Pharmacopsychiatry 1990, 23, 108.

[3] Bomalaski, M. N.; Claflin, E. S.; Townsend, W.; Peterson, M. D. JAMA Neurol. 2017, 74, 1130.

[4] Materia, A.; Basso, N.; Bagarani, M.; Basoli, A.; Speranza, V. Clin. Ter. 1981, 97, 183

[5] Sanger, D. J. Behav. Pharmacol. 1995, 6, 116. 
[6] (a) Hagmann, W. K. J. Med. Chem. 2008, 51, 4359.

(b) Kirk, K. L. Org. Process Res. Dev. 2008, 12, 305.

(c) Meanwell, N. A. J. Med. Chem. 2011, 54, 2529.

(d) Wang, J.; Sánchez-Roselló, M.; Aceña, J.; Pozo, C.; Sorochinsky, A. E.; Fustero, S.; Soloshonok, V. A.; Liu, H. Chem. Rev. 2014, 114, 2432.

[7] Monir, K.; Bagdi, A. K.; Ghosh, M.; Hajra, A. J. Org. Chem. 2015, $80,1332$.

[8] Wu, Y.; Zhang, H.-R.; Jin, R.-X.; Lan, Q.; Wang, X.-S. Adv. Synth. Catal. 2016, 358, 3528.

[9] Wang, R.-N.; Wang, J.-C.; Tang, Q.-X.; Zhao, X.; Wang, J.-F.; Leng, Y.-T.; Wu, Y.-J.; Chang, J.-B.; Wu, Y.-S.; Zhang, Z.-D.; Wang, S.-W. Tetrahedron Lett. 2019, 60, 586.

[10] Ji, X.-M.; We, L.; Chen, F.; Tang, R.-Y. RSC Adv. 2015, 5, 29766.

[11] Chen, X.-Y.; Ding, L.-C.; Li, L.-L.; Li, J.-Y.; Zou, D.-P.; Wu, Y.-J.; Wu, Y.-S. Tetrahedron Lett. 2020, 61, 151538.

[12] Han, S.-J.; Gao, X.-Y.; Wu, Q.-S.; Li, J.-Y.; Zou, D.-P.; Wu, Y.-J.; Wu, Y.-J. Adv. Synth. Catal. 2016, 3361, 1559.

[13] Lefebvre, Q.; Hoffmann, N.; Rueping, M. Chem. Commun. 2016, 52, 2493.

[14] Zhou, Q.-G.; Xu, S.; Zhang, R.-H. Tetrahedron Lett. 2019, 60, 734.

[15] Mi, X.; Kong, Y.-F.; Yang, H.-X.; Zhang, J.-Y.; Pi, C.; Cui, X.-L. Eur. J. Org. Chem. 2020, 1019.

[16] Liu, Y.-F.; Ling, Y.-J.; Lu, L.; Shen, Q. Chin. J. Chem. 2021, 39, 1667.

[17] Electrophilic fluoroalkylating reagents based on sulfonium or selenium-ylide skeleton, see: (a) Liu, Y.-F.; Shao, X.-X.; Lu, L.; Shen, Q. Org. Lett. 2015, 17, 2752.

(b) Zhu, J.-S.; Liu, Y.-F.; Shen, Q. Angew. Chem., Int. Ed. 2016, 55,
9050.

(c) Liu, Y.-F.; Lu, L.; Shen, Q. Angew. Chem., Int. Ed. 2017, 56, 9930.

(d) Zhu, J.-S.; Zheng, H.-L.; Xue, X.-S.; Xiao, Y.-S.; Liu, Y.-F.; Shen, Q. Chin. J. Chem. 2018, 36, 1069.

(e) Ge, H.-M.; Shen, Q. Org. Chem. Front. 2019, 6, 2205.

(f) Liu, Y.-F.; Ge, H.-M.; Lu, L.; Shen, Q. Chin. J. Org. Chem. 2019, 39, 257 (in Chinese)

(刘亚飞，葛航铭，吕龙，沈其龙，有机化学, 2019, 39, 257.)

(g) Hong, X.; Liu, Y.-F.; Lu, L.; Shen, Q. Chin. J. Chem. 2020, 38, 1317.

[18] Selected examples for phosphonium or sulfonium ylides in photoredox-catalyzed reactions: (a) Lu, L.-Q.; Li, T.-R.; Wang, Q.; Xiao, W.-J. Chem. Soc. Rev. 2017, 46, 4135.

(b) Das, M.; Vu, M. D.; Zhang, Q.; Liu, X.-W. Chem. Sci. 2019, 10, 1687.

(c) Vu, M. D.; Leng, W.-L.; Hsu, H.-C.; Liu, X.-W. Asian J. Org. Chem. 2019, 8, 93 .

(d) Xia, X.-D.; Lu, L.-Q.; Liu, W.-Q.; Chen, D.-Z.; Zheng, Y.-H.; Wu, L.-Z.; Xiao, W.-J. Chem.-Eur. J. 2016, 22, 8432.

(e) Yuan, F.; Yan, D.-M.; Gao, P.-P.; Shi, D.-Q.; Xiao, W.-J.; Chen, J.-R. ChemCatChem 2021, 12, 543.

[19] Related work for photo-trifluoromethylation via a donor-acceptor adduct, see: (a) Cheng, Y.-Z.; Yuan, X.-G.; Ma, J.; Yu, S.-Y. Chem.Eur. J. 2015, 21, 8355.

(b) Macé, Y.; Pradet, C.; Popkin, M.; Blazejewski, J.-C.; Magnier, E. Tetrahedron Lett. 2010, 51, 5388.

[20] Pericherla, K.; Kaswan, P.; Khedara, P.; Khungara, B.; Parang, K.; Kumara, A. RSC Adv. 2013, 3, 18923.

(Cheng, F.) 